\title{
Analysis the Behavior of Multi layers Slabs Under Different Parametric Study
}

\author{
Mohamed Abou Elmaaty Amin \\ Assistant Professor of Structural Engineering \\ Faculty of Engineering, Fayoum University \\ Fayoum, Egypt
}

\author{
Mohamed Hussein \\ Professor of Reinforced Concrete \\ Faculty of Engineering, Zagazig University \\ Zagazig, Egypt
}

\author{
Mohamed Ahmed Ahmed \\ Assistant lecture, \\ Giza Engineering Institute,Ministry of Higher Education, Egypt
}

Giza, Egypt

\begin{abstract}
Casting reinforced concrete elements in multi layers become a necessity in special types of structural elements such that flat slabs, raft and deep beams. Study of the behaviour of multi layers slabs under the effect of the applied loads due to different parametric study such as interface surface between layers, the location of layers in compression or tension zone as well as the effect of compressive strength of the different layers. The purpose of this research is to examine the effect of a previous parametric study on the behavior of simply supported slabs. A commercial non-linear finite element program, such as "ANSYS version 12"[1] was used to study the previous slabs. A comparison was made between the slab which was cast as one layer and to that slabs which were cast in multi layers with the different parametric study. the results which obtained from theortical modeling of multi layer slabs showed that the studied parametric has an important effect on the flexural behaviour of slabs.
\end{abstract}

Keywords: Nonlinear, finite element, multi layers, horizontal joints, flexural behavior slabs.

\section{INTRODUCTION}

The aim of this study is to study the behaviour of multi layers reinforced concrete slabs due to different parametric study. A numerical model was used to study such slabs. All codes of the specification or previous work [2] treatment the multi layered slabs (slabs with horizontal joints) by different ways such that ACI Code [3], British Standard: BS 8110 [4], Australian Standard [5], Indian Standard: IS 456:1978 [6] and. Egyptian Code 2017 [7]. In the previous article [8] a comparison was made between the theoretical model and experimental model [9], the results show that the difference between experimental and theoretical analysis varies from $(5 \%$ to $10 \%)$ for ultimate load and (1\% to $10.5 \%)$ for deflection and $(6.5 \%$ to $13 \%)$ for toughness [6]. According to the previous results the numerical models can be used to analyze the behaviour of multi layers slabs under different parametric study as the effect of change the compressive strength of the concrete layers, the location of horizontal joint and the effect of roughness between slab layers.

\section{DESCRIPTION OF STUDIED SLABS}

All slabs are simply supported by four columns with equal span $(110.0 X 110.0 \mathrm{~cm})$ and $(8.0) \mathrm{cm}$ in thickness with top and bottom mesh reinforcement will be $(6 \varnothing 8 / \mathrm{m})$ as shown in Fig. 1. All slabs subjected to uniformly distributed load till failure which is divided into many load steps. Each parametric study contains three slabs, table 1 summarized the description of the studied slabs.
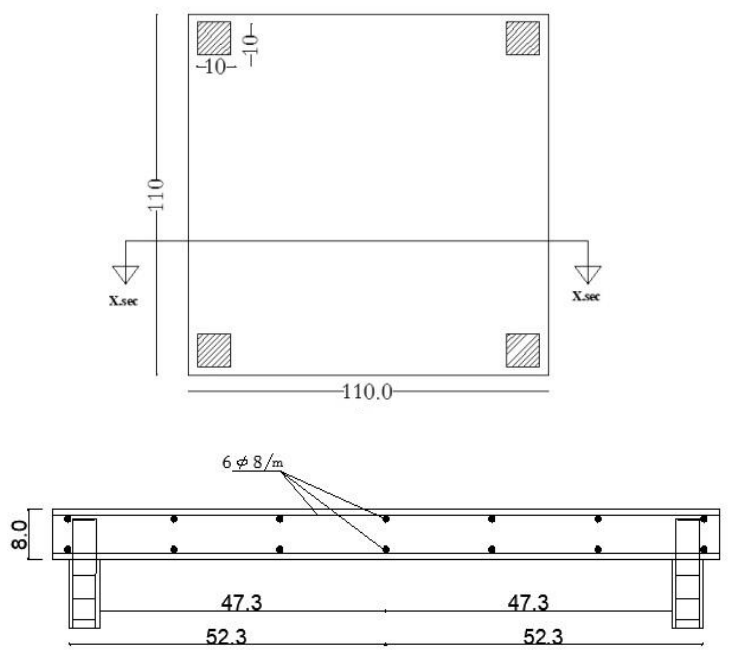

X.sec

Fig.1 Typical concrete dimensions and reinforcement details (All dimensions in $\mathrm{cm}$ )

Table1. Summarized the Description of the Studied Slabs

\begin{tabular}{|c|c|c|c|c|c|c|c|}
\hline $\begin{array}{l}\text { Parametric } \\
\text { study }\end{array}$ & Slab & $\begin{array}{l}\text { Slab } \\
\text { DIM } \\
(\mathrm{cm})\end{array}$ & $\begin{array}{c}\text { Slab } \\
\text { RNFT } \\
\text { TOP\& } \\
\text { BOTT. }\end{array}$ & $\begin{array}{r}\text { No. } \\
\text { of } \\
\text { lay-- } \\
\text {-er }\end{array}$ & $\begin{array}{c}\mathrm{Fcu} \\
(\mathrm{Kg} / \mathrm{c} \\
\left.\mathrm{m}^{2}\right)\end{array}$ & $\begin{array}{c}\text { Thickn- } \\
\text {-ess of } \\
\text { two } \\
\text { layer }\end{array}$ & $\begin{array}{l}\text { Coeffic- } \\
\text {-ient of } \\
\text { roughn- } \\
\text {-ess }\end{array}$ \\
\hline $\begin{array}{l}\text { Refere- } \\
\text {-nce } \\
\text { slab }\end{array}$ & $\mathbf{S}_{\mathbf{0}}$ & $\begin{array}{c}110 * 110 \\
* 8\end{array}$ & $\begin{array}{c}6 \varnothing 8 \\
/ \mathrm{m}^{\prime}\end{array}$ & 1 & 300 & $\begin{array}{c}\text { Total } \\
\text { thickne } \\
\text { ss }\end{array}$ & --- \\
\hline \multirow{2}{*}{$\begin{array}{l}\text { Effect } \\
\text { of } \\
\text { roughn- } \\
\text {-ess }\end{array}$} & $S_{1}$ & $\begin{array}{c}110 * 110 \\
* 8\end{array}$ & $\begin{array}{c}6 \varnothing 8 \\
/ \mathrm{m}^{\prime}\end{array}$ & 2 & 300 & $\begin{array}{c}0.5 \text { ts at } \\
\text { top } \\
\text { \&botto } \\
\text { m }\end{array}$ & 0.25 \\
\hline & $\mathbf{S}_{2}$ & $\begin{array}{c}110 * 110 \\
* 8\end{array}$ & $\begin{array}{c}6 \varnothing 8 \\
/ \mathrm{m}^{\prime}\end{array}$ & 2 & 300 & $\begin{array}{c}0.5 \text { ts at } \\
\text { top } \\
\text { \&botto } \\
\text { m }\end{array}$ & 0.50 \\
\hline
\end{tabular}




\begin{tabular}{|c|c|c|c|c|c|c|c|}
\hline & $\mathbf{S}_{3}$ & $\begin{array}{c}110 * 110 \\
* 8\end{array}$ & $\begin{array}{c}6 \varnothing 8 \\
/ \mathrm{m}^{\prime}\end{array}$ & 2 & 300 & $\begin{array}{c}0.5 \text { ts at } \\
\text { top } \\
\text { \&botto } \\
\text { m }\end{array}$ & 0.75 \\
\hline \multirow{3}{*}{$\begin{array}{l}\text { Effect } \\
\text { of } \\
\text { change } \\
\text { concrete } \\
\text { strength } \\
\text { (Fcu) at } \\
\text { bottom }\end{array}$} & $\mathbf{S}_{4}$ & $\begin{array}{c}110 * 110 \\
* 8\end{array}$ & $\begin{array}{c}6 \varnothing 8 \\
/ \mathrm{m}^{\prime}\end{array}$ & 2 & $\begin{array}{c}200 \text { at } \\
\text { bott } \\
\& 300 t \\
\text { op }\end{array}$ & $\begin{array}{c}0.5 \text { ts at } \\
\text { top } \\
\text { \&botto } \\
\text { m }\end{array}$ & 0.75 \\
\hline & $\mathbf{S}_{5}$ & $\begin{array}{c}110 * 110 \\
* 8\end{array}$ & $\begin{array}{c}6 \varnothing 8 \\
/ \mathrm{m}^{\prime}\end{array}$ & 2 & $\begin{array}{c}250 \text { at } \\
\text { bott } \\
\& 300 t \\
\text { op }\end{array}$ & $\begin{array}{c}0.5 \text { ts at } \\
\text { top } \\
\text { \&botto } \\
\text { m }\end{array}$ & 0.75 \\
\hline & $S_{6}$ & $\begin{array}{c}110 * 110 \\
* 8\end{array}$ & $\begin{array}{c}6 \varnothing 8 \\
/ \mathrm{m}^{\prime}\end{array}$ & 2 & 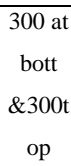 & $\begin{array}{c}0.5 \text { ts at } \\
\text { top } \\
\text { \&botto } \\
\text { m }\end{array}$ & 0.75 \\
\hline \multirow{3}{*}{$\begin{array}{l}\text { Effect } \\
\text { of } \\
\text { change } \\
\text { concrete } \\
\text { strength } \\
\text { (Fcu) at } \\
\text { top }\end{array}$} & $\mathbf{S}_{7}$ & $\begin{array}{c}110 * 110 \\
* 8\end{array}$ & $\begin{array}{c}6 \varnothing 8 \\
/ \mathrm{m}^{\prime}\end{array}$ & 2 & 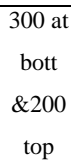 & $\begin{array}{c}0.5 \text { ts at } \\
\text { top } \\
\text { \&botto } \\
\text { m }\end{array}$ & 0.75 \\
\hline & $\mathbf{S}_{8}$ & $\begin{array}{c}110 * 110 \\
* 8\end{array}$ & $\begin{array}{c}6 \varnothing 8 \\
/ \mathrm{m}^{\prime}\end{array}$ & 2 & 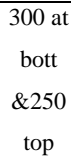 & $\begin{array}{c}0.5 \text { ts at } \\
\text { top } \\
\text { \&botto } \\
\text { m }\end{array}$ & 0.75 \\
\hline & $\mathbf{S}_{9}$ & $\begin{array}{c}110 * 110 \\
* 8\end{array}$ & $\begin{array}{c}6 \varnothing 8 \\
/ \mathrm{m}^{\prime}\end{array}$ & 2 & 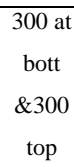 & $\begin{array}{c}0.5 \text { ts at } \\
\text { top } \\
\text { \&botto } \\
\text { m }\end{array}$ & 0.75 \\
\hline \multirow{3}{*}{$\begin{array}{l}\text { Effect } \\
\text { of the } \\
\text { location } \\
\text { of } \\
\text { horizon- } \\
\text {-tal } \\
\text { joint }\end{array}$} & $S_{10}$ & $\begin{array}{c}110 * 110 \\
* 8\end{array}$ & $\begin{array}{c}6 \varnothing 8 \\
/ \mathrm{m}^{\prime}\end{array}$ & 2 & 300 & $\begin{array}{c}\text { Tension } \\
\text { zone }\end{array}$ & 0.75 \\
\hline & $S_{11}$ & $\begin{array}{c}110 * 110 \\
* 8\end{array}$ & $\begin{array}{c}6 \varnothing 8 \\
/ \mathrm{m}^{\prime}\end{array}$ & 2 & 300 & $\begin{array}{c}\text { Natural } \\
\text { zone }\end{array}$ & 0.75 \\
\hline & $S_{12}$ & $\begin{array}{c}110 * 110 \\
* 8\end{array}$ & $\begin{array}{c}6 \varnothing 8 \\
/ \mathrm{m}^{\prime}\end{array}$ & 2 & 300 & $\begin{array}{c}\text { Comp - } \\
\text {-ression } \\
\text { zone }\end{array}$ & 0.75 \\
\hline
\end{tabular}

\section{DESCRIPTION OF FINITE ELEMENT MODEL FOR STUDIED SLABS}

According to the previous article [8], the utilized numerical models can be used to analysis the behavior of multi layers slabs under different parametric study. A finite element program (ANSYS V12) [1] was used to study the effect of horizontal construction joints on reinforced concrete flat slabs. Three-dimensional finite element models were developed to simulate the envelope response of the test slab specimens which listed in table 1. All slabs supported by four edge columns with dimensions $15 \times 15 \times 30 \mathrm{cms}$. All slabs will be subjected to increment uniform load pressure.

\subsection{Mesh configuration}

The mesh which used in the finite element model will be of size ranging from a minimum of $25 \times 25 \times 25 \mathrm{~mm}$ to a maximum of $50 \times 50 \times 50 \mathrm{~mm}$. The finite element mesh is shown in Fig. 2.
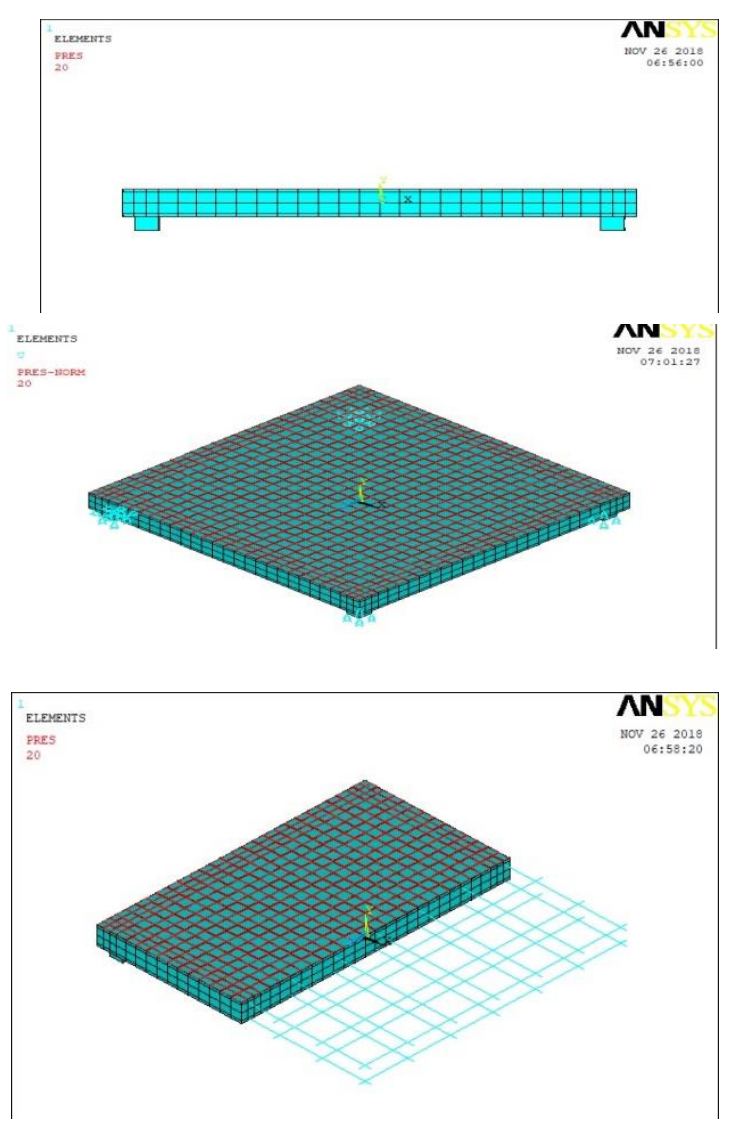

Fig. 2 The finite element mesh

\subsection{Model restraints}

The details of Slab restrains are shown in Fig 3. The left side of the slab was restrained in the vertical direction and the horizontal direction ux, uy, uz. , while at the right side of the slab was restrained in vertical direction only.

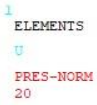

NN Nov 262018

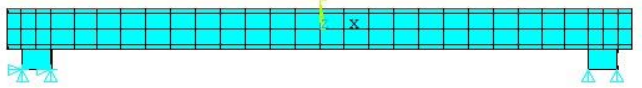

Fig.3 The slab restrains 


\subsection{Loading scheme and loading increments}

The slab was exposed to vertical pressure load located over the area on the upper face of the slab as shown in Fig.4. In (ANSYS) program the load can be applied in steps, each load step is divided to load increments. The solution requires the user to define a maximum number of iterations for each load increment. Within this number of iterations the solution will continue to the next load step if the out of balance forces are within a prescribed limit. The load on the slabs was gradually increased until failure occurred. The size of the load increments was chosen to achieve convergence and at the same time attains an acceptable level of accuracy. Small load increments usually lead to better accuracy and improved convergence with the penalty of more computational cost.

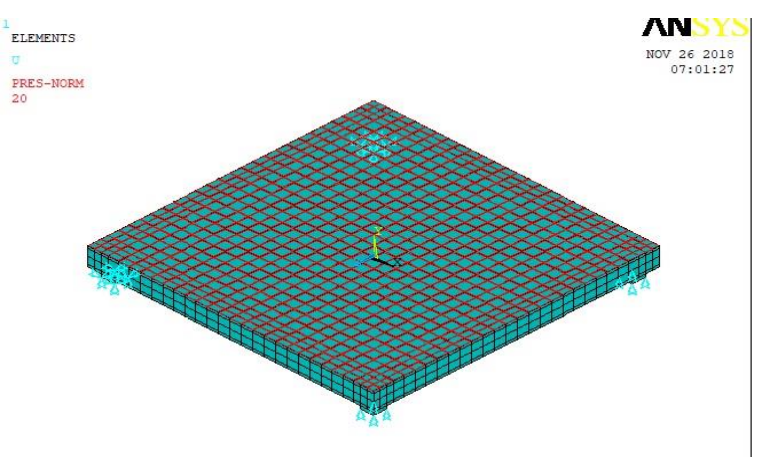

Fig.4 The slab loads

\subsection{Material properties}

The stress-strain relationships for concrete and reinforcing bars as well as all properties of such materials and the finite element models which were used to represent the material such as concrete (SOLID65), reinforcement bars (LINK 180) and supporting element (SOLID 185) were described in details in an article [8].

\section{RESULTS AND DISCUSSION}

Considering the studied parameters of the present study, the following results were observed:

\subsection{Effect of roughness coefficient}

All studied slabs So,S1,S2 and S3 for the same $(\mathrm{Fcu})=300$ $\mathrm{Kg} / \mathrm{cm}^{2}$, the horizontal joint is in mid thickness and friction coefficient values were $(0.25,0.50,0.75)$ for studied slabs $\mathrm{S} 1, \mathrm{~S} 2, \mathrm{~S} 3$ respectively .

\section{A. Ultimate Load}

The ultimate loads for the studied slabs are shown in Table 2 and fig. 5. The figure shows the comparison between the reference slab and the studied slabs due to the changing friction (roughness) coefficient.

Table 2. Effect of roughness coefficients on ultimate loads

\begin{tabular}{|c|c|c|c|c|}
\hline $\begin{array}{c}\text { Case of } \\
\text { study }\end{array}$ & Slab name & $\begin{array}{c}\text { Fcu } \\
\left(\mathrm{kg} / \mathrm{cm}^{2}\right)\end{array}$ & $\begin{array}{c}\text { Friction } \\
\text { coefficient }\end{array}$ & $\begin{array}{c}\text { ultimate load } \\
(\text { ton })\end{array}$ \\
\hline \multirow{3}{*}{$\begin{array}{c}\text { Effect of } \\
\text { roughness } \\
\text { coefficient }\end{array}$} & So & & 1 & 11.37 \\
\cline { 2 - 3 } & $\mathrm{S} 1$ & $\mathrm{~S} 2$ & 0.25 & 7.27 \\
\cline { 2 - 3 } & $\mathrm{S} 3$ & & 0.50 & 8.43 \\
\cline { 5 - 5 } & & & 0.75 & 9.54 \\
\hline
\end{tabular}

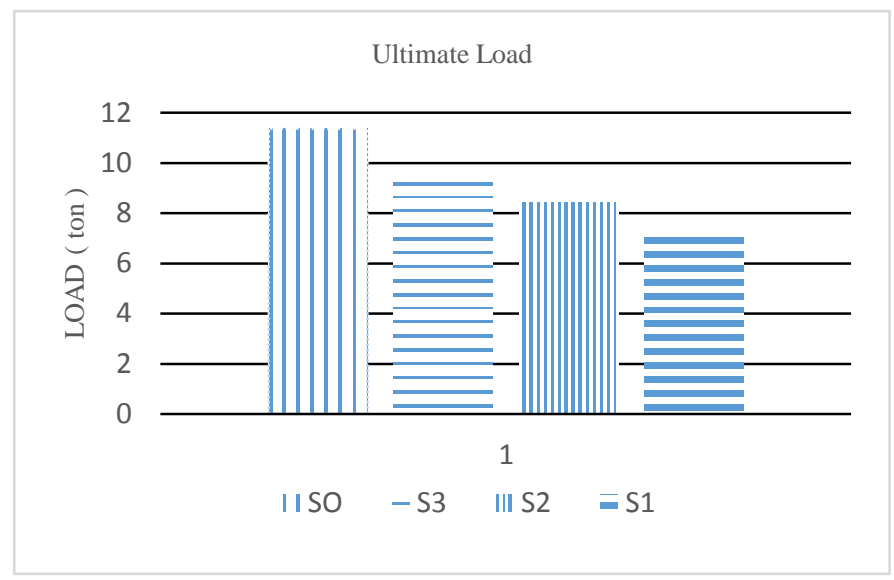

Fig. 4 Effect of roughness coefficent on the Ultimate load of the reference slab(So) and slabs ( S1,S2,S3 )

\section{B. Load-Deflection Response}

Table 3 displays the maximum deflection for the studied slabs (So,S1,S2,S3) due to the changing friction coefficient, while Fig. 5 shows the relation between load and deflection for the previous slabs under the same effect of the parametric study.

Table 3. Effect of roughness coefficients on maximum deflection

\begin{tabular}{|c|c|c|c|c|}
\hline $\begin{array}{c}\text { Case of } \\
\text { study }\end{array}$ & Slab name & $\begin{array}{c}\mathrm{Fcu} \\
\left(\mathrm{kg} / \mathrm{cm}^{2}\right)\end{array}$ & $\begin{array}{c}\text { Friction } \\
\text { coefficient }\end{array}$ & $\begin{array}{l}\text { Deflection } \\
\quad(\mathrm{mm})\end{array}$ \\
\hline \multirow{4}{*}{$\begin{array}{l}\text { Effect of } \\
\text { roughness } \\
\text { coefficient }\end{array}$} & So & \multirow{4}{*}{300} & 1 & 11.3 \\
\hline & S1 & & 0.25 & 10.8 \\
\hline & $\mathrm{S} 2$ & & 0.50 & 12.9 \\
\hline & S3 & & 0.75 & 10.3 \\
\hline
\end{tabular}




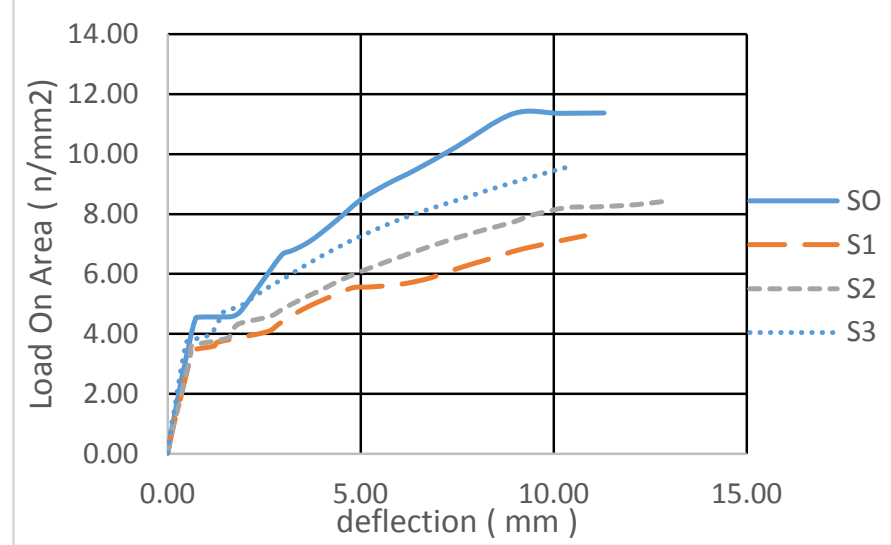

Fig. 5 Effect of roughness coefficent on the relation between Ultimate load and deflection of the reference slab(So) and slabs ( S1,S2,S3)

\section{Toughness}

Flexural toughness or energy absorption is the term used to quantify the energy absorbing capability of concrete, it is the area under the load deflection curve of concrete in flexure up until a deflection equal to the span length divided by 150 [3]. Therefore the flexural toughness values for various slabs calculated at the designated deflection of $7 \mathrm{~mm}$ [3]. Fig. 6 and table 4 show the toughness which obtained from analytical analysis for the studied slabs.

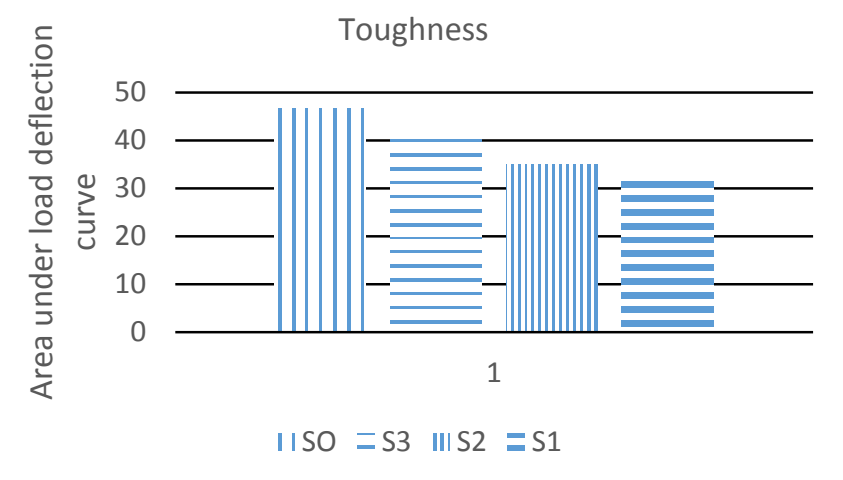

Fig.6 Effect of roughness coefficent on the flexure toughness of the reference slab(So) and slabs ( S1,S2,S3 )

Table 4. Effect of roughness coefficients on maximum deflection

\begin{tabular}{|c|c|c|c|c|}
\hline $\begin{array}{c}\text { Case of } \\
\text { study }\end{array}$ & Slab name & $\begin{array}{c}\text { Fcu } \\
\left(\mathrm{kg} / \mathrm{cm}^{2}\right)\end{array}$ & $\begin{array}{c}\text { Friction } \\
\text { coefficient }\end{array}$ & $\begin{array}{c}\text { Toughness } \\
(\mathrm{T} . \mathrm{mm})\end{array}$ \\
\hline \multirow{2}{*}{$\begin{array}{c}\text { Effect of } \\
\text { changing } \\
\text { concrete } \\
\text { strength } \\
\text { of bottom } \\
\text { laye }\end{array}$} & So & & 1 & 46.74 \\
\cline { 2 - 2 } \cline { 4 - 5 } & $\mathrm{S} 2$ & \multirow{2}{*}{300} & 0.25 & 31.79 \\
\cline { 5 - 5 } & $\mathrm{S} 3$ & & 0.50 & 34.9318 \\
\cline { 5 - 5 } & & & 0.75 & 41.72 \\
\hline
\end{tabular}

\subsection{Effect of change concrete strength of bottom layer}

All studied slabs So,S4,S5 and S6 for the same $(\mathrm{Fcu})=300$ $\mathrm{Kg} / \mathrm{cm}^{2}$ in the top layer and difference in the bottom layer with values $(200,250,300) \mathrm{Kg} / \mathrm{cm}^{2}$ for slabs $\mathrm{S} 4, \mathrm{~S} 5$ and $\mathrm{S} 6$ respectively, friction coefficient will be constant and equall to 0.75 as well as the horizontal joint is in mid thickness for all slabs.

\section{A. Ultimate Load}

The ultimate loads for the studied slabs are shown in Table 5 and fig. 7. The figure shows the comparison between the reference slab and the studied slabs due to the changing of concrete strength for bottom layer from 200 to $300 \mathrm{~kg} / \mathrm{cm}^{2}$.

Table 5. The effect of chang concrete strength for bottom layer on ultimate loads

\begin{tabular}{|c|c|c|c|c|}
\hline $\begin{array}{c}\text { Case of } \\
\text { study }\end{array}$ & $\begin{array}{l}\text { Slab } \\
\text { name }\end{array}$ & $\begin{array}{c}\mathrm{Fcu} \\
\left(\mathrm{kg} / \mathrm{cm}^{2}\right)\end{array}$ & $\begin{array}{c}\text { Friction } \\
\text { coefficient }\end{array}$ & $\begin{array}{l}\text { ultimate load } \\
\text { ( ton ) }\end{array}$ \\
\hline \multirow{7}{*}{$\begin{array}{c}\text { Effect of } \\
\text { changing } \\
\text { concrete } \\
\text { strength } \\
\text { of } \\
\text { bottom } \\
\text { layer }\end{array}$} & So & 300 & 1 & 11.37 \\
\hline & \multirow{2}{*}{ S4 } & 300 top & \multirow{6}{*}{0.75} & \multirow{2}{*}{4.33} \\
\hline & & 200 bott & & \\
\hline & \multirow{2}{*}{ S5 } & 300 top & & \multirow{2}{*}{4.59} \\
\hline & & $250 \mathrm{bott}$ & & \\
\hline & \multirow[t]{2}{*}{ S6 } & 300 top & & \multirow[t]{2}{*}{9.54} \\
\hline & & 300 bott & & \\
\hline
\end{tabular}

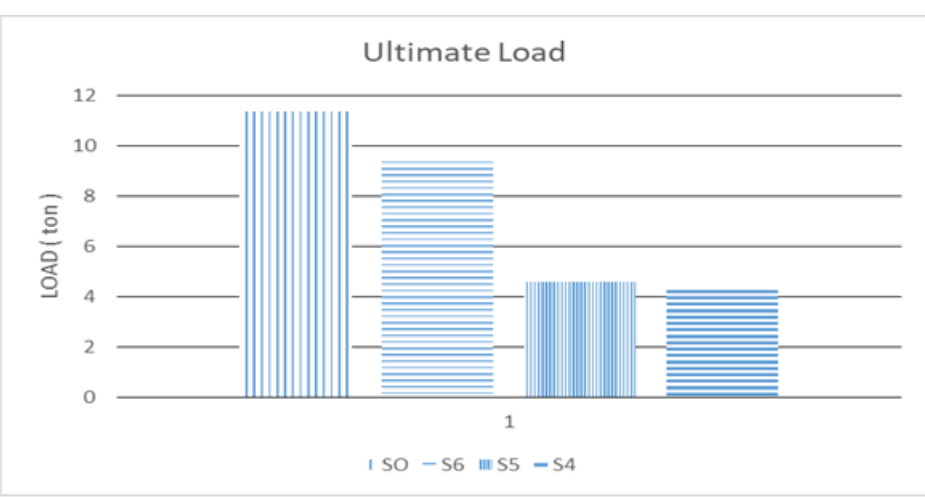

Fig. 7 Effect of chang concrete strength of bottom layer on the Ultimate load of the reference slab(So) and slabs ( S4,S5,S6)

\section{B.Load-Deflection Response}

Fig. 8 shows the relation between load and deflection of the studied slabs, while table 6 shows the maximum deflection for the studied slabs (So,S4,S5,S6) from analytical analysis . 


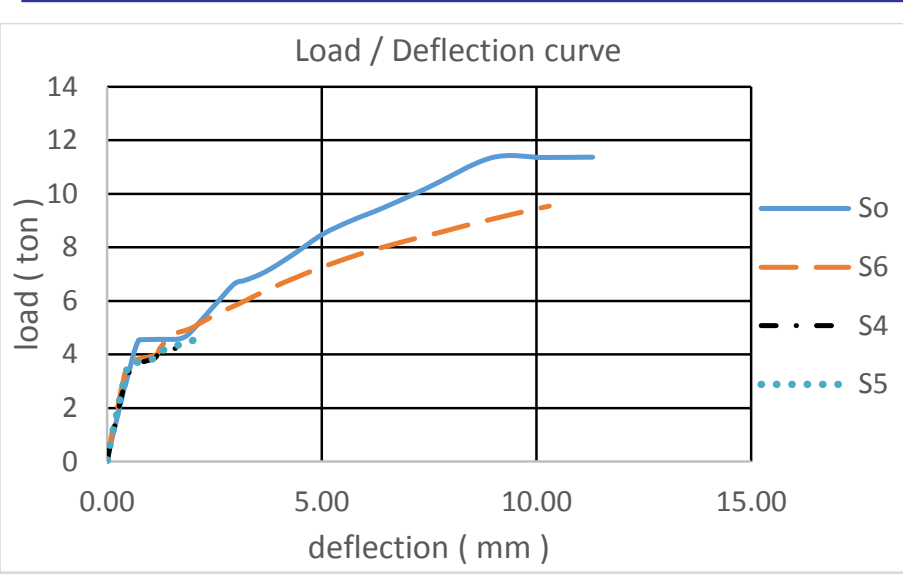

Fig. 8 Effect of chang concrete strength of bottom layer on the relation between load and deflection of the reference slab(So) and slabs ( S4,S5,S6 )

Table 6. Effect of chang concrete strength for bott. layer on max. deflection

\begin{tabular}{|c|c|c|c|c|}
\hline $\begin{array}{c}\text { Case of } \\
\text { study }\end{array}$ & $\begin{array}{c}\text { Slab } \\
\text { name }\end{array}$ & $\begin{array}{c}\text { Fcu } \\
\left(\mathrm{kg} / \mathrm{cm}^{2}\right)\end{array}$ & $\begin{array}{c}\text { Friction } \\
\text { coefficient }\end{array}$ & $\begin{array}{c}\text { Deflection } \\
(\mathrm{mm})\end{array}$ \\
\hline \multirow{7}{*}{$\begin{array}{c}\text { Effect of } \\
\text { changing } \\
\text { concrete } \\
\text { strength } \\
\text { of } \\
\text { bottom } \\
\text { layer }\end{array}$} & So & 300 & 1 & 11.37 \\
\hline & \multirow{2}{*}{ S4 } & 300 top & \multirow{6}{*}{0.75} & \multirow{2}{*}{1.9} \\
\hline & & 200 bott & & \\
\hline & \multirow{2}{*}{ S5 } & 300 top & & \multirow{2}{*}{2.21} \\
\hline & & 250 bott & & \\
\hline & \multirow{2}{*}{ S6 } & 300 top & & \multirow{2}{*}{10.3} \\
\hline & & 300 top & & \\
\hline
\end{tabular}

\section{Toughness}

Fig. 9 and table 7 show the toughness which obtained from analytical analysis for tested group slabs So, S4, S5 and S6.

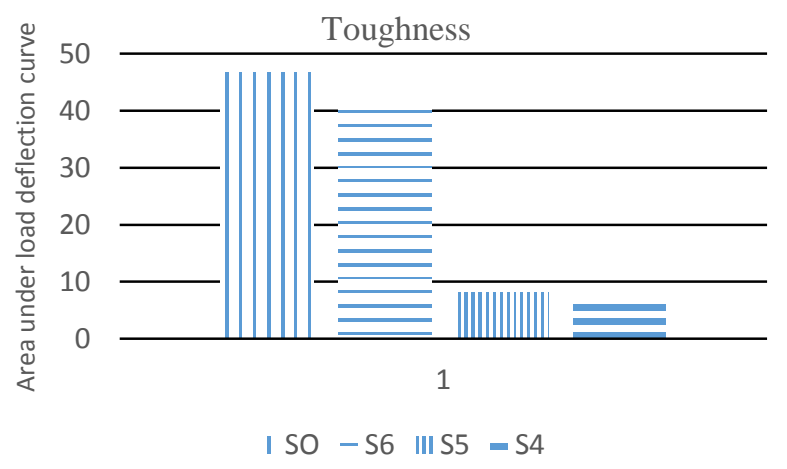

Fig. 9 Effect of chang concrete strength of bottom layer on toughness of the reference slab(So) and slabs ( S4,S5,S6 )

Table 7. Effect of chang concrete strength for bott. layer on toughness

\begin{tabular}{|c|c|c|c|c|}
\hline $\begin{array}{c}\text { Case of } \\
\text { study }\end{array}$ & $\begin{array}{c}\text { Slab } \\
\text { name }\end{array}$ & $\begin{array}{c}\mathrm{Fcu} \\
\left(\mathrm{kg} / \mathrm{cm}^{2}\right)\end{array}$ & $\begin{array}{c}\text { Friction } \\
\text { coefficient }\end{array}$ & $\begin{array}{l}\text { Toughness } \\
\text { (t.mm) }\end{array}$ \\
\hline \multirow{6}{*}{$\begin{array}{l}\text { Effect of } \\
\text { changing } \\
\text { concrete } \\
\text { strength } \\
\text { of } \\
\text { bottom } \\
\text { layer }\end{array}$} & So & 300 & 1 & 46.74 \\
\hline & \multirow{2}{*}{ S4 } & 300 top & \multirow{5}{*}{0.75} & \multirow{2}{*}{6.4} \\
\hline & & 200 bott & & \\
\hline & S5 & 300 top & & 8.05 \\
\hline & \multirow{2}{*}{ S6 } & 300 top & & \multirow{2}{*}{41.72} \\
\hline & & 300 bott & & \\
\hline
\end{tabular}

\subsection{Effect of change concrete strength on top layer}

All studied slabs So,S7,S8 and S9 for the same (Fcu) $=300 \mathrm{Kg} / \mathrm{cm}^{2}$ in bottom layer and difference in top layer with values $(200,250,300) \mathrm{Kg} / \mathrm{cm}^{2}$ for studied slabs S7,S8 and S9 respectively, friction coefficient will be constant and equall to 0.75 for all studied slabs and the horizontal joint is in mid thickness also in all slabs.

\section{A. Ultimate Load}

The ultimate loads for the studied slabs are shown in Table 8 and fig. 10. The figure show the comparison between the reference slab and the studied slabs due to the changing of concrete strength for bottom layer from 200 to $300 \mathrm{~kg} / \mathrm{cm}^{2}$.

Table 8. Effect of chang concrete strength for top layer on ultimate loads

\begin{tabular}{|c|c|c|c|c|}
\hline $\begin{array}{c}\text { Case of } \\
\text { study }\end{array}$ & $\begin{array}{c}\text { Slab } \\
\text { name }\end{array}$ & $\begin{array}{c}\text { Fcu } \\
\left(\mathrm{kg} / \mathrm{cm}^{2}\right)\end{array}$ & $\begin{array}{c}\text { Friction } \\
\text { coefficient }\end{array}$ & $\begin{array}{c}\text { ultimate load } \\
\text { ( ton ) }\end{array}$ \\
\hline \multirow{7}{*}{$\begin{array}{c}\text { Effect of } \\
\text { changing } \\
\text { concrete } \\
\text { strength } \\
\text { of top } \\
\text { layer }\end{array}$} & So & 300 & 1 & 11.37 \\
\hline & \multirow{2}{*}{ S7 } & 300 bott & \multirow{6}{*}{0.75} & \multirow{2}{*}{6.54} \\
\hline & & 200 top & & \\
\hline & \multirow{2}{*}{ S8 } & 300 bott & & \multirow{2}{*}{7.82} \\
\hline & & 250 top & & \\
\hline & \multirow{2}{*}{ S9 } & 300 bott & & \multirow{2}{*}{9.54} \\
\hline & & 300 top & & \\
\hline
\end{tabular}

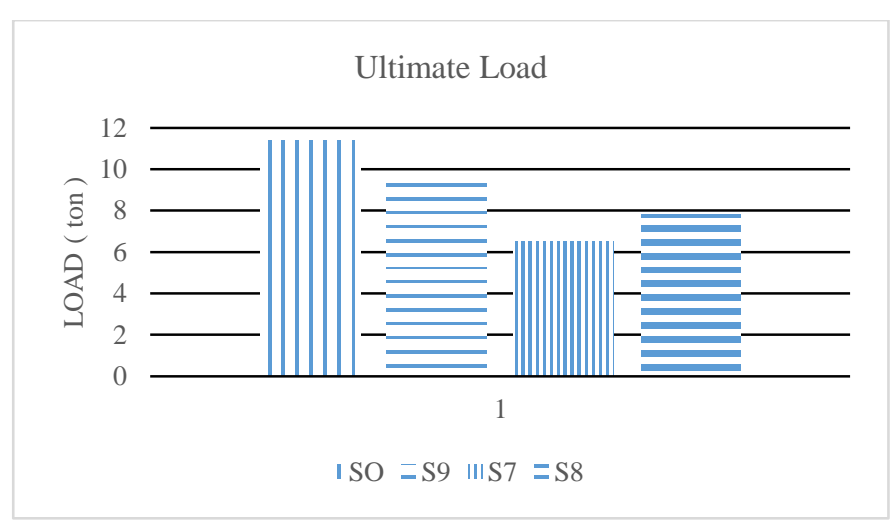

Fig. 10 Effect of chang concrete strength of top layer on the Ultimate load of the reference slab(So) and slabs ( S7,S8,S9)

\section{B. Load-Deflection Response}

Fig. 11 and table 9 show the relation between load-deflection relation and the maximum deflection respectively for the studied slabs (So,S7,S8,S9) as a result of analytical study. 


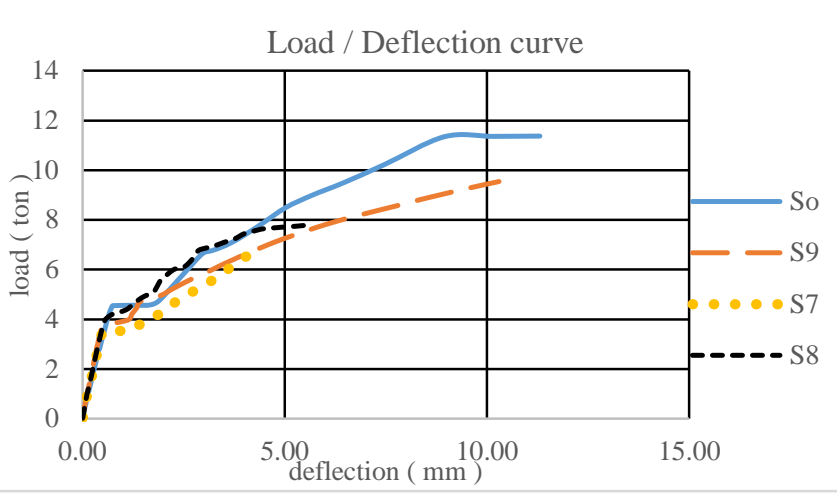

Fig. 11 Effect of chang concrete strength of top layer on the load deflection relation of the reference slab(So) and slabs $(\mathrm{S} 7, \mathrm{~S} 8, \mathrm{~S} 9)$

Table 9. Effect of chang concrete strength for top layer on maximum deflection

\begin{tabular}{|c|c|c|c|c|}
\hline $\begin{array}{l}\text { Case of } \\
\text { study }\end{array}$ & $\begin{array}{l}\text { Slab } \\
\text { name }\end{array}$ & $\begin{array}{c}\mathrm{Fcu} \\
\left(\mathrm{kg} / \mathrm{cm}^{2}\right)\end{array}$ & $\begin{array}{c}\text { Friction } \\
\text { coefficient }\end{array}$ & Deflection $(\mathrm{mm})$ \\
\hline \multirow{6}{*}{$\begin{array}{c}\text { Effect of } \\
\text { changing } \\
\text { concrete } \\
\text { strength } \\
\text { of top } \\
\text { layer }\end{array}$} & So & 300 & 1 & 11.30 \\
\hline & S7 & $\frac{300 \text { bott }}{200 \text { top }}$ & \multirow{5}{*}{0.75} & 4.31 \\
\hline & \multirow{2}{*}{ S8 } & 300 bott & & \multirow{2}{*}{5.7} \\
\hline & & 250 top & & \\
\hline & \multirow{2}{*}{ S9 } & 300 bott & & \multirow{2}{*}{10.3} \\
\hline & & 300 top & & \\
\hline
\end{tabular}

\section{Toughness}

Fig. 12 and table 10 show the toughness which obtained from analytical analysis for tested group slabs So, S7, S8 and S9.

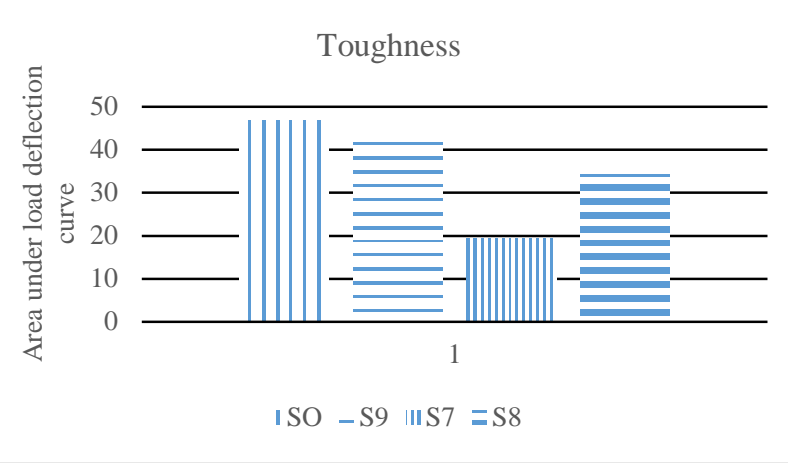

Fig. 12 Effect of chang concrete strength of top layer on toughness of the reference slab(So) and slabs ( S7,S8,S9 )

Table 10 Effect of chang concrete strength of top layer on toughness

\begin{tabular}{|c|c|c|c|c|}
\hline $\begin{array}{c}\text { Case of } \\
\text { study }\end{array}$ & $\begin{array}{c}\text { Slab } \\
\text { name }\end{array}$ & $\begin{array}{c}\text { Fcu } \\
\left(\mathrm{kg} / \mathrm{cm}^{2}\right)\end{array}$ & $\begin{array}{c}\text { Friction } \\
\text { coefficient }\end{array}$ & Toughness (t.mm) \\
\hline \multirow{5}{*}{$\begin{array}{c}\text { Effect of } \\
\text { changing } \\
\text { concrete } \\
\text { strength } \\
\text { of top } \\
\text { layer }\end{array}$} & So & 300 & 1 & 46.74 \\
\hline & S7 & $\frac{300 \text { bott }}{200 \text { top }}$ & \multirow{4}{*}{0.75} & 19.41 \\
\hline & S8 & $\frac{300 \text { bott }}{250 \text { ton }}$ & & 34.22 \\
\hline & \multirow{2}{*}{ S9 } & 300 bott & & \multirow{2}{*}{41.72} \\
\hline & & 300 top & & \\
\hline
\end{tabular}

\subsection{Effect of change in location of horizontal joint}

To investigate the effect of the location of the horizontal joint all studied slabs So,S10,S11 and S12 have the same (Fcu) $=300 \mathrm{Kg} / \mathrm{cm}^{2}$ and the coefficient of roughness equall to 0.75 . The location of horizontal joint was located in ( tension zone, neutral zone and compression zone) for studied slabs S10,S11 and $\mathrm{S} 12$ respectively,

\section{A. Ultimate Load}

The ultimate loads for the studied slabs are shown in Table 11 and fig. 13. The figure shows the A comparison between the reference slab and the studied slabs due to the changing of concrete strength for bottom layer from 200 to 300 $\mathrm{kg} / \mathrm{cm}^{2}$.

Table 11. Effect of changing horizontal joint location on ultimate loads

\begin{tabular}{|c|c|c|c|}
\hline $\begin{array}{c}\text { Case of } \\
\text { study }\end{array}$ & $\begin{array}{c}\text { Slab } \\
\text { name }\end{array}$ & Horizontal joint location & $\begin{array}{c}\text { ultimate load } \\
(\text { ton })\end{array}$ \\
\hline \multirow{4}{*}{$\begin{array}{c}\text { Effect of } \\
\text { changing } \\
\text { horizontal } \\
\text { joint } \\
\text { location }\end{array}$} & So & no & 11.37 \\
\hline & $\mathrm{S} 10$ & Compression zone & 5.60 \\
\hline & S11 & Natural zone & 9.54 \\
\hline & $\mathrm{S} 12$ & Tension zone & 4.53 \\
\hline
\end{tabular}

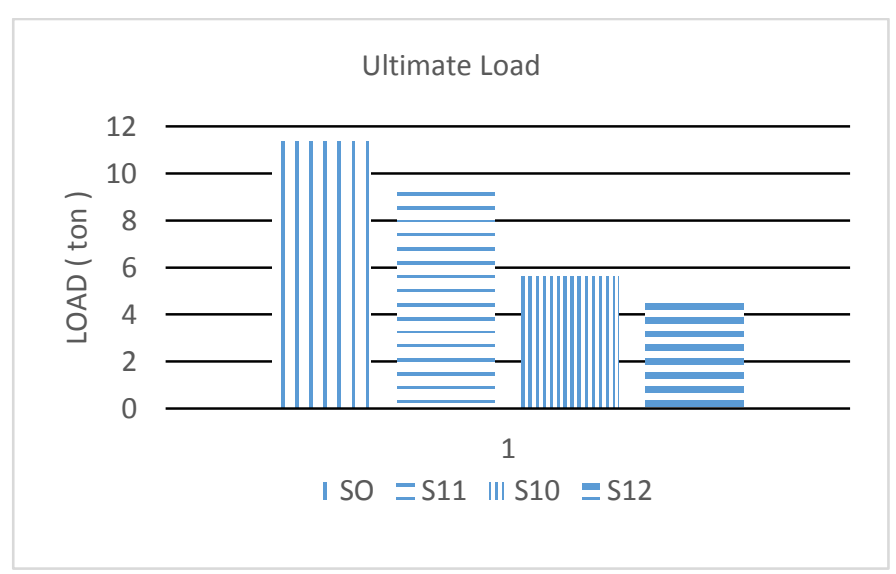

Fig. 13 Effect of changing horizontal joint location on the Ultimate load

\section{B. Load-Deflection Response}

Fig. 14 shows the relation between load and deflection of the slabs (So,S10,S11,S12) while table 10 show the maximum deflection for the previous slabs due to the results which obtained from analytical analysis. 


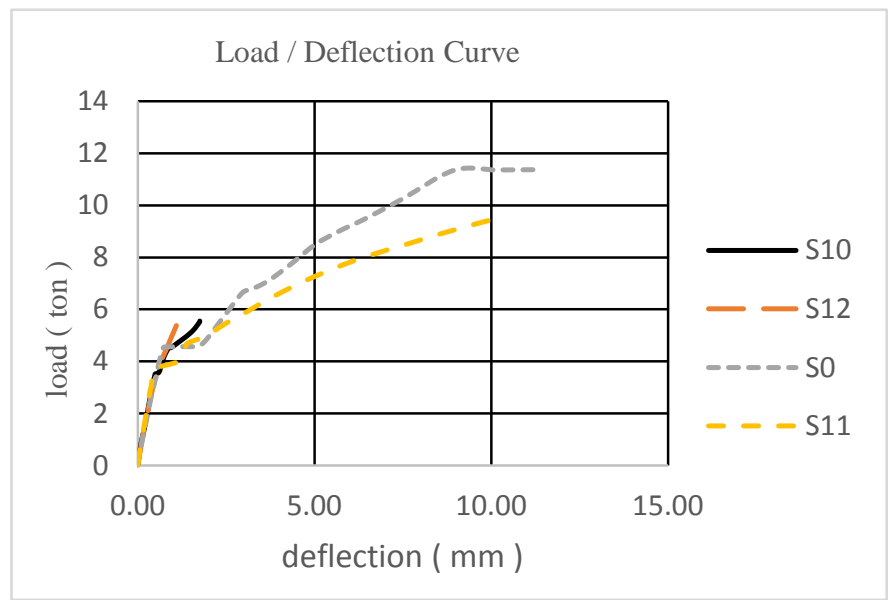

Fig. 14 Effect of changing horizontal joint location on the load deflection relation

Table 12. Effect of changing horizontal joint location on maximum deflection

\begin{tabular}{|c|c|c|c|}
\hline $\begin{array}{c}\text { Case of } \\
\text { study }\end{array}$ & $\begin{array}{c}\text { Slab } \\
\text { name }\end{array}$ & Horizontal joint location & Deflection (mm) \\
\hline \multirow{4}{*}{$\begin{array}{l}\text { Effect of } \\
\text { changing } \\
\text { horizontal } \\
\text { joint } \\
\text { location }\end{array}$} & So & no & 11.30 \\
\hline & $\mathrm{S} 10$ & Compression zone & 2 \\
\hline & $\mathrm{S} 11$ & Natural zone & 10.3 \\
\hline & S12 & Tension zone & 0.95 \\
\hline
\end{tabular}

\section{Toughness}

Fig. 15 and table 13 show the toughness which obtained from analytical analysis for tested group slabs So, S10, S11 and S12.

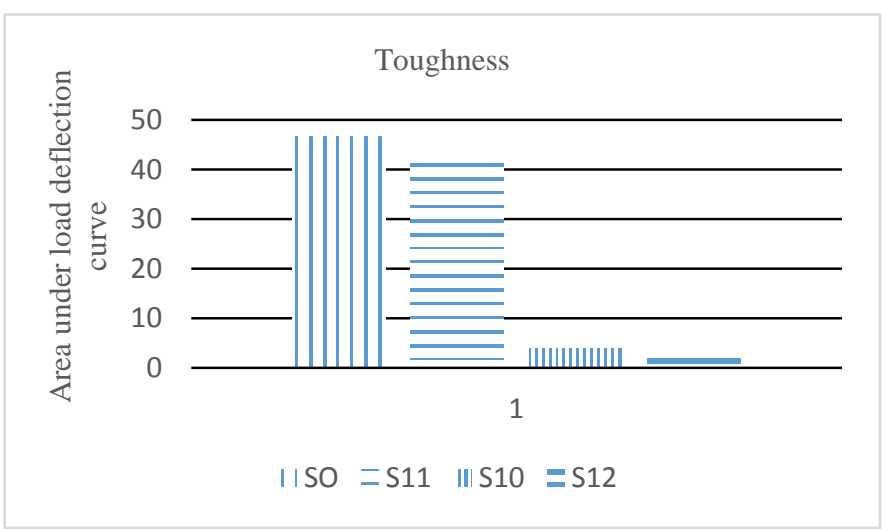

Fig. 15 Effect of changing horizontal joint location on toughness

Table 13 Effect of changing changing horizontal joint on toughness

\begin{tabular}{|c|c|c|c|}
\hline $\begin{array}{c}\text { Case of } \\
\text { study }\end{array}$ & $\begin{array}{c}\text { Slab } \\
\text { name }\end{array}$ & Horizontal joint location & $\begin{array}{c}\text { Toughness } \\
\text { (t.mm ) }\end{array}$ \\
\hline \multirow{4}{*}{$\begin{array}{c}\text { Effect of } \\
\text { changing } \\
\text { horizontal } \\
\text { joint } \\
\text { location }\end{array}$} & So & no & 46.74 \\
\hline & S10 & Compression zone & 3.98 \\
\hline & S11 & Natural zone & 41.72 \\
\hline & $\mathrm{S} 12$ & Tension zone & 2.47 \\
\hline
\end{tabular}

\section{CONCLUSIONS}

According to the obtained results from the analytical study, the following conclusions can be drawn:

- When the friction coefficient is increased between layers causes the increase in ultimate load.

- At the same load as increasing in friction coefficient causes decreasing in deflection values.

- As increasing friction coefficient between layers as increasing the toughness values of the studied slabs.

- For a bottom layer when increasing concrete strength causes an increase in ultimate load.

- Change in a concrete strength in the bottom layer causes early failure for the studied slab except if the two-layer has the same concrete strength.

- Due to the previous conclusion the toughness and deflection decrease in comparison with reference slab and slab with multi layer which has the same concrete strength for both layer.

- Changing the concrete strength of the top layer and keep the strength of bottom layer constant and higher than that for the top layer, it will give good performance for the flexure behaviour of the studied slabs.

- When a horizontal construction joint located in tension zone it will be the worst case of the slabs for the flexural behaviour than if it located in the compression zone.

- The best location for the horizontal joint in the natural zone (mid thickness) for the flexural behaviour. 


\section{REFERENCES}

[1]. ANSYS Verification Manual "Release 12.0" ANSYS, Inc., United States.

[2]. Hess, J. R., Jan., "RCC Lift-Joint Strength", Concrete International, 2002, pp. 50-56.

[3]. ACI Committee 318R-89, "Commentary on Building Code Requirements for Reinforced,Concrete", 1989.

[4]. British Standard: BS 8110:, "Structural Use of Concrete", Part 1, Code of Practice for Design and Construction of Construction Joint, 1985.

[5]. Australian Standard: AS: 1480-1982.

[6]. Indian Standard: IS: 456-1978.

[7]. Egyptian Code of Practice for Reinforced Concrete Structures: Construction and Design, 2017.

[8]. Mohamed abou elmaaty amin, Mohamed Mahmoud hussein, Mohamed Ahmed Ahmed" Nonlinear Analysis of the Effect of Horizontal Construction Joint on the Flexural Behavior of Reinforced Concrete Slabs" IOSR Journal of Mechanical and Civil Engineering (IOSR-JMCE)

e-ISSN: 2278-1684,p-ISSN: 2320-334X, Volume 15, Issue 6 Ver. I (Nov. - Dec. 2018), PP 45-54

[9]. Metwally, I. M., and Issa, M. S., "Influence Of Horizontal Construction Joint On The Flexural Behavior Of Reinforced Concrete Slabs " HBRC Journal, Vol.3, No. 3 December 2007 pp (81-91). 